\title{
Do pollution and climate influence respiratory tract infections in children?
}

\author{
Saulo Duarte Passos ${ }^{1 *}$, Rosa Estela Gazeta ${ }^{2}$, Ana Paula Felgueiras ${ }^{3}$, Patrí́cia Costa Beneli ${ }^{4}$, Micheline de S. Z. S. Coelho 5 \\ ${ }^{1}$ Full Professor; Associate professor at the Pediatrics Department of the Jundiaí Medical School, Jundiaí, SP, Brazil \\ ${ }^{2}$ Master of Medicine, assistant instructor at the Pediatrics Department of the Jundiaí Medical School; Master of Pediatrics from the University of São Paulo Medical School - FMUSP, São Paulo, SP, Brazil \\ ${ }^{3}$ Master of Health Sciences; assistant instructor at the Pediatrics Department of the Jundiaí Medical School, Jundiaí, SP, Brazil \\ ${ }^{4}$ Master of Health Sciences ICB USP, Biologist, São Paulo, SP, Brazil \\ DDoctorate, Post-doctorate researcher at the University of São Paulo Medical School - FMUSP, Meteorologist, São Paulo, SP, Brazil
}

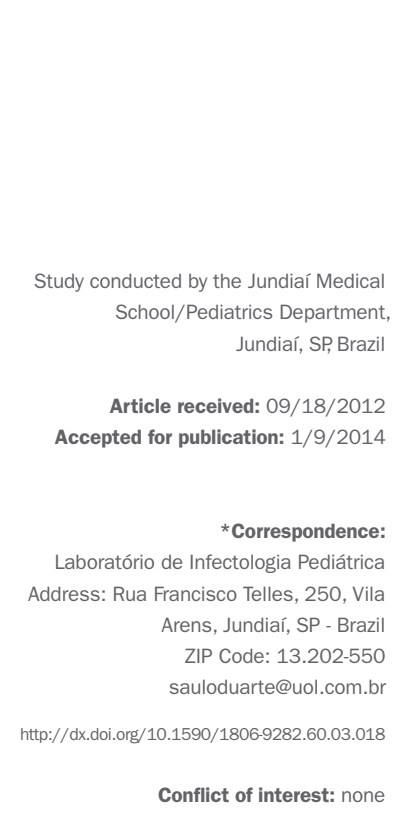

\section{Abstract}

To review if pollution and climate changes can influence respiratory tract infections in children. Data source: articles published on the subject in PubMed, SciELO, Bireme, EBSCO and UpTodate were reviewed. The following inclusion criteria were considered: scientific papers between 2002 and 2012, study design, the pediatric population, reference documents such as the CETESB and World Health Organization Summary of the data: We analyzed research that correlated respiratory viruses and climate and/or pollution changes. Respiratory syncytial virus has been the virus related most to changes in climate and humidity. Other "old and new" respiratory viruses such as Human Bocavirus, Metapneumovirus, Parechovirus and Parainfuenza would need to be investigated owing to their clinical importance. Although much has been studied with regard to the relationship between climate change and public health, specific studies about its influence on children's health remain scarce.

Uniterms: climate change, air pollution, respiratory tract infections, child.

\section{Historical PERSPECTIVE}

The perception that "the climate is changing" has been verified throughout history and different levels of impact on the people's health have been reported. ${ }^{1}$

In ancient China, it was accepted that atypical climate variations could be accompanied by epidemics and that excessive physical strain associated to climate variations was a major cause of illness. ${ }^{2}$

Hippocrates, in his classic "On Airs, Waters, and Places", discusses environmental factors connected to illness, defending an ecological and multi-causal concept of health/disease that involves mankind's reactions to aggressions originating from its natural environment.

The historical evidence of the action of climate on epidemics has been observed less than starvation and malnutrition. Drought and famine have had a major impact on human health, as one of the most serious adverse effects of the climate over the 12.000 years of humanity's history. ${ }^{3}$ However, climate change caused by humans is one of the largest social, environmental and public health challenges to be faced in this century. ${ }^{4}$
This change could influence numerous factors such as mortality and morbidity rates, hospital admissions ${ }^{5}$ and the transmission of infectious diseases, with acute respiratory infections (ARIs) deserving special attention.

On a global scale, ARIs associated with pneumonia are the main cause of mortality in infancy, mainly in those under five years of age, both in developed and developing countries. ${ }^{6,7}$

These manifestations in children can be noted for their heterogeneity, both in terms of physiology and performance against ARIs, where the risk of complications is not the same between different age ranges.

Pneumonia is caused by a combination of risk factors related to the host, the environment and the infection. ${ }^{8}$

Studies on preschool children in developed and developing countries indicate that the majority of respiratory tract infections generally have a viral etiology ${ }^{9,10}$ and the clinical diagnosis of ARIs in the lower tract (pneumonia and bronchiolitis) are often confused mainly in younger children. 
Over time, atmospheric pollution has also taken on a significant role in respiratory diseases, ${ }^{1}$ as one of the main environmental risk factors. A variety of direct effects, such as heat waves, flooding and storms, and indirect effects, such as the distribution and intensity of the transmission of infectious diseases have been systematically identified. ${ }^{11}$

In a recent review of the issue, $\mathrm{Xu}$, Sheffield, Hu et al. ${ }^{12}$ (2012) indicated the impact of climate changes on child health. In Table 1, we have outlined the effects on the respiratory tract in children.

\section{TABLE 1 Impact of climate changes on child health ${ }^{12}$}

\begin{tabular}{|c|c|c|}
\hline Impact & Exposure & Result \\
\hline \multirow[t]{2}{*}{ Direct } & Air pollution & $\begin{array}{l}\text { Decreased pulmonary function } \\
\text { Asthma } \\
\text { Birth defects } \\
\text { Other respiratory diseases } \\
\text { Mortality }\end{array}$ \\
\hline & Heat waves & $\begin{array}{l}\text { Increased respiratory diseases } \\
\text { Increased hospital admissions } \\
\text { Hyperthermia } \\
\text { Possibility of birth defects }\end{array}$ \\
\hline \multirow[t]{3}{*}{ Indirect } & $\begin{array}{l}\text { Water reduction } \\
\text { (quality and } \\
\text { quantity) }\end{array}$ & Respiratory diseases \\
\hline & Allergic diseases & Asthma \\
\hline & Infectious diseases & \\
\hline
\end{tabular}

\section{Pollution}

Global warming caused by the anthropogenic effect is currently one of the major scientific paradigms. The Intergovernmental Panel on Climate Change (IPCC) in 2007 revealed evidence that a large part of the global warming observed in the last fifty years is attributed to the emission of carbon dioxide and other gases. As a result, we have verified an increase in the frequency of extreme meteorological events. These events have caused serious damage to health, whether through death caused by climatic catastrophes or changes in the regional microclimates, favoring the appearance or escalation of diseases. ${ }^{13}$

\section{HoW DO POLLUTANTS ACT?}

In Brazil, the air quality standards were established by CONAMA Resolution $n^{\circ} 3 / 1990$, and divided into pri- mary and secondary standards. ${ }^{14}$ However, the limits for particles, ozone, nitrogen dioxide and sulfur dioxide adopted by the World Health Organization (WHO) in 2005 present values up to three times lower than the national standards (Table 2).

TABLE 2 Air quality standards for key pollutants, according to Conama Resolution No3, dated 28/06/1990, and $\mathrm{WHO}$

\begin{tabular}{|c|c|c|c|c|}
\hline \multirow{2}{*}{ Pollutant } & \multirow{2}{*}{$\begin{array}{l}\text { Sampling } \\
\text { Time }\end{array}$} & \multicolumn{2}{|c|}{ Conama Standards } & \multirow{2}{*}{$\begin{array}{l}\text { WHO } \\
\text { Standards }\end{array}$} \\
\hline & & $\begin{array}{l}\text { Primary } \\
\text { standard } \\
\left(\mu \mathrm{g} / \mathrm{m}^{3}\right)\end{array}$ & $\begin{array}{l}\text { Secondary } \\
\text { standard } \\
\left(\mu \mathrm{g} / \mathrm{m}^{3}\right)\end{array}$ & \\
\hline \multirow[t]{2}{*}{$\begin{array}{l}\text { Inhalable } \\
\text { particles }\end{array}$} & 24 hours* & 150 & 100 & $\begin{array}{l}50(\mathrm{PM} 10)^{* *} \\
25(\mathrm{PM} 2.5)^{* *}\end{array}$ \\
\hline & AGM & 60 & 50 & \\
\hline \multirow{2}{*}{$\begin{array}{l}\text { Sulfur } \\
\text { dioxide }\end{array}$} & 24 hours* & 365 & 100 & 20 \\
\hline & AAM & 80 & 40 & \\
\hline \multirow{4}{*}{$\begin{array}{l}\text { Carbon } \\
\text { monoxide }\end{array}$} & $15 \mathrm{~min}$ & NR & NR & 10,000 \\
\hline & $30 \mathrm{~min}$ & NR & NR & 60,000 \\
\hline & 1 hour* & $\begin{array}{l}40,000 \\
(35 \mathrm{ppm})\end{array}$ & $\begin{array}{l}40,000 \\
(35 \mathrm{ppm})\end{array}$ & 30.000 \\
\hline & 8 hours* & $\begin{array}{l}10,000 \\
\text { (9ppm) }\end{array}$ & $\begin{array}{l}10,000 \\
(9 \mathrm{ppm})\end{array}$ & 10. 000 \\
\hline Ozone & $1 h^{*}$ & 160 & 160 & 100 \\
\hline \multirow{2}{*}{$\begin{array}{l}\text { Nitrogen } \\
\text { dioxide }\end{array}$} & $1 h^{*}$ & 320 & 190 & 200 \\
\hline & AAM & 100 & 100 & 40 \\
\hline
\end{tabular}

* Not to be exceeded more than once per year

* Value not to be exceeded more than 3 days per year

NR: no reference AGM - annual geometric mean AAM- annual arithmetic mean

The State of São Paulo adapted the state air quality standards to the WHO standards (State Decree n ${ }^{\circ} 59113$, dated $04 / 23 / 2013$ ) and consequently changed the criteria for acute air pollution episodes and the structure of the air quality index. This that the air quality considered good today will have a regular value from now on.

More details about the matter can be consulted on the São Paulo State Environmental Company (CETESB) website. ${ }^{15}$ 
Brazil has therefore been alerted about its less stringent legislation, as the country may be breathing more harmful air, especially for groups with greater vulnerability to pollution, such as children.

The United States of America legally defines the maximum limit for the concentration of a pollutant in the atmosphere, which guarantees the protection of health and the environment, although there is no consensus on the size of the particle and on the extention of the damage to health. ${ }^{16}$

Pollutants affecting air quality include inhalable particles $\left(\mathrm{MP}_{10}\right)$. To put it simply, ${ }^{17}$ inhalable particles can be defined as those whose aerodynamic diameter is less than $10 \mu \mathrm{m}\left(\mathrm{MP}_{10}\right)$, while fine inhalable particles are defined as less than $2.5 \mu \mathrm{m}$ (MP2.5) and coarse inhalable particles, between 2.5 and $10 \mu \mathrm{m}$. The size of the particle, surface and chemical composition of the particulate material determine the risk that exposure to this agent represents for human health. Fine particles, owing to their smaller size, penetrate deeply into the respiratory system, and may affect the alveoli.

Among the air pollutants we can highlight Sulfur Dioxide $\left(\mathrm{SO}_{2}\right)$ and Ozone $\left(\mathrm{O}_{3}\right)$. The $\mathrm{SO}_{2}$ released into the atmosphere is oxidized, forming sulfuric acid $\left(\mathrm{H}_{2} \mathrm{SO}_{4}\right)$, considered as the most irritating acid aerosol $(\mathrm{pH}<1)$ for the respiratory tract. Due to its high solubility and absorption rate in the airways, it may result in a decrease in the individual's immunological system, increasing susceptibility to acute infections.

The levels of ozone $\left(\mathrm{O}_{3}\right)$ resulting from the reaction of volatile organic compounds such as hydrocarbons and nitrogen oxide in the presence of sunlight increase considerably between the end of spring and the start of autumn. Ozone is a potent cytotoxic oxidant that affects the more distal regions of the airways, with corrosion of tissues as well as irritation of the eyes and upper airways.

A hotter and wetter climate, temperature inversions (meteorological phenomenon that can delay the dispersion of pollutants) and fires can worsen the air quality of many cities, causing the above-mentioned damage.

\section{Pollutants and Child health}

Due to climate changes, the air pollutant standards are changing in various urbanized areas worldwide, with a significant effect on respiratory health. ${ }^{18}$

Children belong to a group with higher vulnerability to climate changes and pollutants than adults. ${ }^{18,19}$ This fact can be partly explained by the immaturity of the child's respiratory system, were the development of the lungs and thorax is progressive and continues until ten years of age, as well as the capacity to adapt to temperature changes. A less effective capacity to adapt to the heat than adults has been verified in children.

The particles of atmospheric pollutants with a larger diameter are retained in the upper airways, while smaller ones may reach the alveoli. Inhalable particulate material transports gases absorbed on their surface, leading them to the more distal portions of the airways, where gas exchange occurs. In the lung, these particles are phagocytized by the alveolar macrophages, and then removed via the mucociliary apparatus or lymphatic system, ${ }^{20}$ causing increase risk of respiratory infection.

In our area, Saldiva et al. ${ }^{21}$ demonstrated an association between morbidity/mortality owing to respiratory diseases in children and an increase in atmospheric pollutants, especially particulate material. ${ }^{21}$ In São Paulo, a significant increase (over 20\%) was demonstrated in pediatric services at emergency units on days with higher atmospheric pollution levels. ${ }^{22}$

In Australia, a directly proportional relationship was verified between abrupt increases in air pollution and an increase in the number of hospitalizations of children. ${ }^{23}$ In six Italian cities an association was found between air pollution $\left(\mathrm{CO}\right.$ and $\left.\mathrm{SO}_{2}\right)$ and a $2.7 \%$ increase in wheezing $(\mathrm{CI} 95=0.5$ 4.9) and acute gastroenteritis (CI95 $=1.5-5.3)$ in children under two years old during visits to emergency services. ${ }^{24}$

A recent study conducted with children from 1 to 9 years in twelve cities in two different regions of California suggests that the level of exposure to particulate material $\left(\mathrm{MP}_{2,5}\right)$ in the environment is associated with an increase in hospitalizations caused by respiratory tract diseases such as ARIs, pneumonia and asthma. This association became more evident in populations with low socioeconomic status. ${ }^{25}$

The relationship between climate changes and the impairment of those with allergies and bronchial asthma are well established, causing the formation and persistence of pollen, spores and certain pollutants in the atmosphere..$^{26,27}$

In relation to viral diseases, Martins et al.(2002) investigated the effects caused by atmospheric pollution on the morbidity of pneumonia and influenza in the elderly, concluding that $\mathrm{O}_{3}$ and $\mathrm{SO}_{2}$ are directly related to these diseases, with an increase in the number of cases at health services. ${ }^{28}$ 
Another aspect to be considered is maternal exposure to air pollution before and during pregnancy that could alter the immunocompetence of the offspring, increasing the risk of the child developing health conditions later in life, including asthma and allergies. ${ }^{29}$

This period is especially susceptible to in utero exposure to toxins. For the health of pregnant women there is accumulating evidence of an increase in premature labor and retarded intrauterine growth, which elevate neonatal and infant mortality rates, especially an increase in infantile malignant diseases (Hodgkin's lymphoma and leukemia). ${ }^{30}$

\section{Climate changes and respiratory diseases}

The evaluation of the effects related to the impact of climate changes on health is extremely complex. It requires an integrated, interdisciplinary evaluation by health professionals, climatologists, social, biological, physical and chemical scientists, epidemiologists etc. in order to analyze the relationships between social, economic, biological, ecological and physical systems and their relationship to climate changes. ${ }^{31}$

Researchers have studied a lot about the predicted effects of climate change on public health, but little has been specifically written about climatic effects on child health. ${ }^{3}$

Some studies related climate change to infectious, contagious diseases but there are few publications describing the impact of climate changes on ARIs in childhood. ${ }^{18,32}$

In 1916, Hamer, cited by Jubb, already warned of the influence of climate on certain infectious diseases such as measles and scarlet fever. ${ }^{33}$ Some observations have been made for vector-borne diseases such as malaria, dengue, leishmaniasis and yellow fever, ${ }^{34}$ where climate changes have had their greatest impact. ${ }^{35}$ Recently, in our region, cases of Lyme-like Disease in Brazilian children have been described, transmitted by a tick, where there was an association with seasonality. ${ }^{36,37}$

Recent studies have indicated a relationship between some respiratory viruses such as Influenza/ $\mathrm{H}_{1} \mathrm{~N}_{1}$ and climate change on child health. Humidity appears to perform an important role, with absolute humidity associated with greater infection rates for the influenza virus. ${ }^{31,32}$
Prel et al. ${ }^{38}$ studied the correlation with climate factors in a sample composed of 3461 children hospitalized for acute respiratory diseases. There was a positive correlation between Adenovirus (hAdV), type A and B influen$\mathrm{za}$ (FLU A and FLUB) and respiratory syncytial virus (RSV) and temperature, and between rhinovirus (hRV) and relative air humidity. It can therefore be concluded that the seasonal variation of ARIs caused by these pathogens can be explained by meteorological influences. ${ }^{38}$

RSV infections appear to have a correlation with an increase atmospheric humidity. Omer et al., ${ }^{39}$ studied 2878 children with $748 \mathrm{RSV}(+)$ cases using a multivariate analysis with a lag of 8 days and the occurrence of rain. It was noted that the episodes were associated in $60 \%$ of the cases, given that when relative humidity moved from $1 \%$ to $6 \%$ there was a $39 \%$ increase in the cases of RSV ${ }^{39}$.

A study conducted in the city of Jundiaí (SP) by Felqueiras ${ }^{40}$ verified that there was an association between climatological factors and respiratory infections caused by RSV. In the period from 2005 to 2007 an ecological time-series study was conducted on 575 children aged less than 15 years with respiratory symptoms. The study of viral antigens using immunofluorescence detected $29.9 \%$, with $20,3 \%$ relating to RSV; $5 \%$ to HPIV; $2,8 \%$ to IA; $0.3 \%$ to $\mathrm{IB}$ and $1.4 \%$ to $\mathrm{AD}$, and $67.7 \%$ negative cases and $2.4 \%$ inconclusive. The lags presenting the highest correlations were lag3 for temperature and lag 1 for particulate material. After 24 hours (lag1 - 1 day) of the emission of particulate material and after 72 hours (lag3 - 3 days) from the fall in temperature there was an increase in RSV cases at visits to the emergency room.

Attempts to explain this fact have been reported in the literature. We can highlight an investigation about the stability of RSV: stable RSV aerosols were prepared and maintained at different relative humidity levels. The recovery of the virus was higher at a higher relative humidity and the stability of the aerosol was at a maximum with relative humidity of $60 \%$. This indicates that humidity performs and important role and can affect the transmission of the virus ${ }^{41}$.

The human respiratory syncytial virus has been the subject of many studies correlating its incidence with climate change and pollution. In Table 3 we can check the results of some of these studies. 
TABLE 3 Characteristics of the association between climate and pollution and respiratory syncytial virus in children

\begin{tabular}{|c|c|c|c|}
\hline Author/Year & Location & Association & Conclusion \\
\hline $\begin{array}{l}\text { Reese \& Marchette }{ }^{42} \\
1991\end{array}$ & Hawaii, USA & October/April & Rotation of serotypes $A$ and $B$ \\
\hline Chew et al. ${ }^{43} 1998$ & Singapore & $\begin{array}{l}\text { Association with low relative } \\
\text { humidity, temperature variation, } \\
\text { day and daily temperature } \\
\text { variation }\end{array}$ & There is a seasonal relationship with ARI in the tropics \\
\hline Vieira et al. ${ }^{44} 2001$ & São Paulo & May/June & $\begin{array}{l}\text { There is a correlation in a determined period in the city of } \\
\text { São Paulo }\end{array}$ \\
\hline Azamorano et al. ${ }^{45} 2003$ & Chile & $\begin{array}{l}\text { Acute bronchiolitis, climate } \\
\text { factors and environmental } \\
\text { contamination }\end{array}$ & $\begin{array}{l}\text { No association between environmental variations or air } \\
\text { pollution and the number of clinical and emergency } \\
\text { consultations in patients under one year old }\end{array}$ \\
\hline Yusuf et al. ${ }^{46} 2007$ & $\begin{array}{l}\text { Buffalo, Miami, } \\
\text { Tucson, Canada, } \\
\text { Mexico, India and } \\
\text { Chile. }\end{array}$ & $\begin{array}{l}\text { Humidity }(45-65 \%) \text { and high } \\
\text { temperature }\end{array}$ & $\begin{array}{l}\text { RSV infections were continuous throughout the year, reaching } \\
\text { a peak in summer and the start of autumn. In temperate } \\
\text { climates the maximum RSV activity was in the winter. In areas } \\
\text { where temperatures remained colder throughout the year, RSV } \\
\text { activity again became nearly continuous }\end{array}$ \\
\hline Omer et al. ${ }^{47} 2008$ & Indonesia & $\begin{array}{l}\text { Climate, weather and } \\
\text { geographical characteristics of } \\
\text { RSV respiratory illness }\end{array}$ & $\begin{array}{l}\text { Rain, humidity and temperature increased the incidence of } \\
\text { illness caused by RSV }\end{array}$ \\
\hline Karr et al. ${ }^{48} 2008$ & Washington & $\begin{array}{l}\text { Particulate material and other } \\
\text { air pollutants derived from } \\
\text { traffic and bronchiolitis caused } \\
\text { by RSV }\end{array}$ & $\begin{array}{l}\text { Increase in the number of bronchiolitis hospitalizations } \\
\text { caused by RSV during the peak seasons of the occurrence of } \\
\text { the virus }\end{array}$ \\
\hline Meerhoff et al. ${ }^{49} 2009$ & Netherlands & $\begin{array}{l}\text { Increased relative air humidity, } \\
\text { minimum temperature was } \\
\text { negatively and cloudy weather } \\
\text { positively related }\end{array}$ & $\begin{array}{l}\text { The combination of low temperature and high humidity } \\
\text { contributes more to RSV infections }\end{array}$ \\
\hline Prel et al. ${ }^{50} 2009$ & Germany & $\begin{array}{l}\text { Positive meteorological } \\
\text { influence for ARI }\end{array}$ & $\begin{array}{l}\text { Influenza A, RSV and Adenovirus correlation with } \\
\text { temperature. Rhinovirus correlates with humidity }\end{array}$ \\
\hline Sloan et al. ${ }^{51} 2011$ & Review article & $\begin{array}{l}\text { Pollution, climate and social/ } \\
\text { demographic factors and } \\
\text { seasonal respiratory viruses: } \\
\text { RSV influenza and rhinovirus }\end{array}$ & $\begin{array}{l}\text { Seasonality, cold climate, humidity, natural immunity cycle } \\
\text { and individual antigenic variation }\end{array}$ \\
\hline $\begin{array}{l}\text { Vandini et al. }{ }^{52} \\
2013\end{array}$ & Italy & $\begin{array}{l}\text { Infection by the respiratory } \\
\text { syncytial virus in infants and } \\
\text { correlation with meteorological } \\
\text { factors and } \\
\text { air pollutants }\end{array}$ & $\begin{array}{l}\text { The tendency for RSV epidemics in Bologna (Italy) is related } \\
\text { to the average minimum temperature and average } \\
\text { concentration of } \mathrm{MP}_{10}\end{array}$ \\
\hline
\end{tabular}

Beneli ${ }^{53}$ verified that there was an association between climatological factors and respiratory infections caused by Parainfluenza. An association was noted between $\mathrm{MP}_{10}$ and lag3 (three days) and the infection caused by Parainfluenza. Considering the total of the other viruses studied (Influenza A and B, Adenovirus and RSV) the associ- ation was highlighted between minimum temperature and lag1 (one day) and $\mathrm{NO}_{2} \cdot{ }^{53}$

At a molecular level, temperature is recognized for influencing the fusion of the virus with cellular membranes, enabling it to enter the cell and replicate. Viruses cannot fuse with a cell efficiently and inject the genetic material 
at low temperatures. Cold air increases the viral excretion of influenza in infected individuals. ${ }^{55}$

Cold temperatures decreases the functionality of the nasal epithelium with a reduced capacity to protect the lower respiratory tract, causing disorganization of the epithelium and nasal mucociliary defense mechanisms and leaving the distal acinar airways more vulnerable to reactive gases and particulate material. ${ }^{56}$

Recent reviews have demonstrated the significant adverse effects of atmospheric pollution and climate on the pulmonary health of children, especially asthmatics, with decrease pulmonary function ${ }^{54}$ and increased prevalence of allergic diseases. ${ }^{55}$

Another aspect that has been questioned is the action of vitamin D on ARIs. The low production of vitamin D in winter in temperate climates reduces immunity and a deficiency of this vitamin predisposes children to respiratory infections, especially the influenza virus. ${ }^{58} \mathrm{Howev}-$ er, more research needs to be conducted in order to verify the real role of this vitamin in ARIs.

\section{Conclusion}

Drops in temperature and the emission of particulate material are events that have been related most with acute respiratory infections by the respiratory syncytial virus.

The research about this issue is scarce, both for known viruses as well as new emerging respiratory viruses.

\section{Recommendations}

New strategies should be incorporated into health programs aimed at minimizing the damage of pollution and climate changes. Health professionals, especially those caring for children, should understand the importance of this issue, incorporating these concepts into their daily practice. As such, subsidies could be offered for greater knowledge of these problems and their solutions, thereby minimizing the damaging effects on future generations. ${ }^{59}$

\section{Resumo}

A poluição e o clima podem influenciar as infecções respiratórias em crianças?

Rever se a poluição e as alterações do clima podem influenciar nas infecções respiratórias de crianças. Fontes de dados: foram revisados artigos publicados sobre o tema no PubMed, SciELO, Bireme, EBSCO e UpToDate. Os seguintes critérios de inclusão foram levados em consideração: trabalhos científicos entre 2002 e 2012, delineamento de estudo, população pediátrica, documentos de referência, como Cetesb e Organização Mundial da Saúde. Síntese dos dados: foram analisadas as pesquisas que correlacionavam vírus respiratórios e alterações do clima e/ou poluição. O vírus sincicial respiratório tem sido o vírus mais relacionado com alterações climáticas e umidade. Outros "velhos e novos" vírus respiratórios, como parainfluenza (VPH), metapneumovírus humano (hMPV), bocavírus $(\mathrm{HBoV})$ e parechovirus $(\mathrm{HPeV})$, precisariam ser investigados pela sua importância clínica. Embora muito se tenha estudado sobre a relação das mudanças climáticas na saúde coletiva, estudos específicos sobre sua influência na saúde das crianças ainda são escassos.

Unitermos: mudança climática; poluição do ar; infecções respiratórias, criança.

\section{References}

1. Mackenbach JP. Global environmental change and human health: a public health research agenda. J Epidemiol Community Health. 2007;61(2):92-4.

2. Sampaio J. História da medicina tradicional china. León: Fundación Europea de Medicina Tradicional China, Fundación Universitaria Iberoamericana (FUNIBER), Universidad de León; 2008.

3. McMichael AJ. Insights from past millennia into climatic impacts on human health and survival. Proc Natl Acad Sci USA. 2012;109(13):4730-7.

4. IPCC. Summary for Policymakers. In: Climate Change 2007: The Physical Science Basis. Contribution of Working Group I to the Fourth Assessment Report of the Intergovernmental Panel on Climate Change. Cambridge: Cambridge University Press; 2007.

5. Nair H, Simões EA, Rudan I, Gessner BD, Azziz-Baumgartner E, Zhang JS et al. Global and regional burden of hospital admissions for severe acute lower respiratory infections in young children in 2010: a systematic analysis. Lancet. 2013;381(9875):1380-90.

6. Graham NMH. The epidemiology of acute respiratory infections in children and adults: a global perspective. Epidemiol Rev. 1990;12:149-78.

7. Rudan I, O’Brien KL, Nair H, Liu L, Theodoratou E, Qazi S et al. Child Health Epidemiology Reference Group (CHERG). Epidemiology and etiology of childhood pneumonia in 2010: estimates of incidence, severe morbidity, mortality, underlying risk factors and causative pathogens for 192 countries. J Glob Health. 2013;3(1):10401.

8. Rudan I, Boschi-Pinto C, Biloglav Z, Mulholland K, Campbell H. Epidemiology and etiology of childhood pneumonia. Bull World Health Organ. 2008;86(5):408-16.

9. Waters D, Theodoratou, Campbell H, Rudan I, Chopra M. Optimizing community case management strategies to achieve equitable reduction of childhood pneumonia mortality: An application of equitable Impact Sensitive tool (eQuISt) in five low- and middle-income countries. J Glob Health. 2012;2(2):20402

10. Ruuskanen O, Lahti E, Jennings LC, Murdoch DR. Viral pneumonia. Lancet. 2011;377(9773):1264-75.

11. Campbell-Lendrum D, Woodruff R. Climate change: quantifying the health impact at national and local levels. World Health Organization; 2007. (WHO Environmental Burden of Disease Series No. 14)

12. Xu Z, Sheffield PE, Hu W, Su H, Yu W, Qi X, Tong S. Climate change and children's health -- a call for research on what works to protect children. Int J Environ Res Public Health. 2012;9(9):3298-316.

13. Coelho MSZS, Saldiva PHN. Use of the "Urban Air Index" to estimate morbidity and mortality in large cities: case study São Paulo, Brazil. 19th Congress International of the Biometeorology; 2011 Dez 5-9; Auckland, New Zealand.

14. Conselho Nacional do Meio ambiente CONAMA. Available at: http://www. $\mathrm{mma}$.gov.br/port/conama/legiabre.cfm?codlegi=100. 
15. Companhia Ambiental do Estado de São Paulo (CETESB). Poluentes. Available at: http://www.cetesb.sp.gov.br/ar/Informacoes-Basicas/21Poluentes.

16. United State Environmental Protection Agency. [cited 2013 aug 4]. Available at: http://www.epa.gov/airquality/particlepollution/actions.html.

17. World Health Organization. Regional Office for Europe. Review of evidence on health aspects of air pollution: REVIHAAP Project. Copenhagen: WHO Regional Office for Europe; 2013.

18. Ostro B, Chesnut L. Assessing the health benefits of reducing particulate matter air pollution in the United States. Environ Res. 1998;76(2):94-106.

19. Balbus JM, Malina C. Identifying vulnerable subpopulations for climate change health effects in the United States. J Occup Environ Med. 2009;51(1):33-7.

20. Cançado JED, Braga A, Pereira LAA, Arbex MA, Saldiva PHN, Santos UP. Repercussões clínicas da exposição à poluição atmosférica. J Bras Pneumol. 2006;32(Supl 1):S5-S11.

21. Saldiva PH, Lichtenfels AJ, Paiva PS, Barone IA, Martins MA, Massad E et al. Association between air pollution and mortality due to respiratory diseases in children in São Paulo, Brazil: a preliminary report. Environ Res.1994;65(2):218-25.

22. Lin AC, Martins MA, Farhat SL, Pope III CA, Conceição GMS, Anastácio MV et al. Air pollution and respiratory illness of children in São Paulo, Brazil. Paediatr Perinat Epidemiol. 1999;13(4):475-87.

23. Barnett AG, Williams GM, Schwartz J, Neller AH, Best T, Petroeschevsky AL et al. Air pollution and child respiratory health: a case-crossover study in Australia and New Zealand. Am J Respir Crit Care Med. 2005;171(11):1272-8.

24. Orazzo F, Nespoli L, Ito K, Tassinari D, Giardina D, Funis M et al. Air pollution, aeroallergens, and emergency room visits for acute respiratory diseases and gastroenteric disorders among young children in six Italian cities. Environ Health Perspect. 2009;117(11):1780-5

25. Yap PS, Gilbreath S, Garcia C, Jareen N, Goodrich B. The influence of socioeconomic markers on the association between fine particulate matter and hospital admissions for respiratory conditions among Children. Am J Public Health. 2013;103(4):695-702

26. Lin AC, Martins MA, Farhat SL, Pope III CA, Conceição GMS, Anastácio MV et al. Air pollution and respiratory illness of children in São Paulo, Brazil. Paediatr Perinat Epidemiol. 1999;13(4):475-87.

27. Barnett AG, Williams GM, Schwartz J, Neller AH, Best T, Petroeschevsky AL et al. Air pollution and child respiratory health: a case-crossover study in Australia and New Zealand. Am J Respir Crit Care Med. 2005;171(11):1272-8.

28. Martins LC, Latorre MRDO, Cardoso MRA, Gonçalves FLT, Saldiva PHN, Braga ALF. Poluição atmosférica e atendimentos por pneumonia e gripe em São Paulo, Brasil. Rev Saúde Pública. 2002;36(1):88-94

29. Baïz N, Slama R, Béné MC, Charles MA, Kolopp-Sarda MN, Magnan A et al. Maternal exposure to air pollution before and during pregnancy related to changes in newborn's cord blood lymphocyte subpopulations. The EDEN study cohort. BMC Pregnancy Childbirth. 2011;11:87.

30. Parinaz, P, Kelishadi R. What health professionals should know about the health effects of air pollution and climate change on children and pregnant mothers? Iran J Nurs Midwifery Res. 2011;16(3): 257-64

31. McMichael AJ, Woodruff RE, Hales S. Climate change and human health: present and future risks. Lancet. 2006;367(9513):859-69.

32. Steel J, Palese P, Lowen AC. Transmission of a 2009 pandemic influenza virus shows a sensitivity to temperature and humidity similar to that of an H3N2 seasonal strain. J Virol. 2011;85(3):1400-2.

33. Jubb G. The influence of the weather on the incidence of certain infectious diseases. Br Med J. 1917;2(2954):197-8.

34. Organização Pan-Americana da Saúde, Organização Mundial da Saúde. Mudanças climáticas e ambientais e seus efeitos na saúde: cenários e incertezas para o Brasil. Brasília (DF); 2008. p. 25-32.

35. Sellman J, Hamilton D. Global climate change and human health. Minn Med. 2007;90(3):47-50

36. Passos SD, Gazeta RE, Latorre MR, Durigon EL, Gauditano G, Yoshinari N. Características clínico-epidemiológicas da doença Lyme-símile em crianças. Rev Assoc Med Bras. 2009; 55(2):139-44.

37. Lowen AC, Mubareka S, Steel J, Palese P. Influenza virus transmission is dependent on relative humidity and temperature. PLoS Pathog. 2007;3:e151.

38. Prel JB, Puppe W, Grondahl B, Knuf M, Weigl JAI, Schaaff F et al. Are meteorological parameters associated with acute respiratory tract infections? Clin Infect Dis. 2009;49(6):861-8.
39. Omer SB, Zutanito A, Sarwo H, Linehan M, Djelantik IGG, Mercer D et al. Climatic, temporal, and geographic characteristics of respiratory syncytial virus disease in a tropical island population. Epidemiol Infect. 2008;136(10):1319-27.

40. Felqueiras AZ. Associação entre os poluentes atmosféricos, as variáveis climáticas/metereológicas e as infecções respiratórias agudas (IRA) causada pelo Vírus Sincicial respiratório em menores de 15 anos, na cidade de Jundiaí, São Paulo. Jundiaí: Faculdade de Medicina de Jundiaí; 2013.

41. Rechsteinerand J. Inactivation of respiratory syncytial virus in aerosol. J Gen Virol. 1969;5(4):405-10

42. Reese PE, Marchette NJ. Respiratory syncytial virus infection and prevalence of subgroups A and B in Hawaii. J Clin Microbiol. 1991;29(11):2614.

43. Chew FTS, Doraisingham S, AE Ling, Kumarasinghe G, Lee BW. Seasonal trends of viral respiratory tract infections in the tropics. Epidemiol Infect. 1998;121(1):121-8

44. Vieira SE, Gilio AE, Miyao CR, Hein N, Betta SL, Lotufo JPB et al. Sazonalidade do virus respiratório sincicial na Cidade de São Paulo, SP. Pediatria (Säo Paulo). 2002;24(1/2):73-4.

45. Zamorano W, Márquez S, Aránguiz JL, Bedregal P, Sánchez I. Relación entre bronquiolitis aguda con factores climáticos y contaminación ambiental. Rev Méd Chile. 2003;131(10):1117-22.

46. Yusuf S, Piedimonte G, Auais A, Demmler G, Krishnan S, Van Caeseele P et al. The relationship of meteorological conditions to the epidemic activity of respiratory syncytial virus. Epidemiol Infect. 2007;135(7):1077-90.

47. Omer B, Sutanto A, Sarwo H, Linehan M, Djelantik G, Mercer D et al. Climatic, temporal, and geographic characteristics of respiratory syncytial virus disease in a tropical island population. Epidemiol Infect. 2008;136(10):1319-27.

48. Karr CJ, Rudra CB, Miller KA, Gould TR, Larson T, Sathyanarayana S et al. Infant exposure to fine particulate matter and traffic and risk of hospitalization for RSV bronchiolitis in a region with lower ambient air pollution. Environ Res. 2009;109(3): 321-7.

49. Meerhoff TJ, Paget WJ, Kimpen JLL. Variation of respiratory syncytial virus and the relation with meteorological factors in different winter seasons. Pediatr Infect Dis J. 2009;28(10):860-6

50. Prel JB, Puppe W, Grondahl B, Knuf M, Weigl JAI, Schaaff F et al. Are meteorological parameters associated with acute respiratory tract infections? Clin Infect Dis. 2009;49(6):861-8.

51. Sloan C, Moore ML, Hartert T. Impact of pollution, climate, and sociodemographic factors on spatiotemporal dynamics of seasonal respiratory viruses. Clin Transl Sci. 2011;4(1):48-54.

52. Vandini S, Corvaglia L, Alessandroni R, Aquilano G, Marsico C, Spinelli M et al. Respiratory syncytial virus infection in infants and correlation with meteorological factors and air pollutants. Ital J Pediatr. 2013;39(1):1.

53. Beneli PC. Associação entre fatores meteorológicos, poluentes atmosféricos e ocorrência de viroses respiratórias causadas pelo parainfluenza vírus humano em crianças atendidas num serviço de emergência em Jundiaí, SP: destaque ao parainfluenza vírus humano (HPIV). São Paulo: Instituto de Ciências Biomédicas, Universidade de São Paulo; 2010.

54. Li S, Williams G, Jalaludin B, Baker P. Panel studies of air pollution on children's lung function and respiratory symptoms: a literature review. J Asthma. 2012;49(9):895-910.

55. D’Amato G, Baena-Cagnani CE, Cecchi L, Annesi-Maesano I, Nunes C, Ansotegui I et al. Climate change, air pollution and extreme events leading to increasing prevalence of allergic respiratory diseases. Multidiscip Respir Med. 2013;8(1):12

56. Lowen AC, Mubareka S, Steel J, Palese P. Influenza virus transmission is dependent on relative humidity and temperature. PLoS Pathog. 2007;3(10):e151.

57. Calderón-Garcidueñas L, Valencia-Salazar G, Rodriguez-Alcaraz A, Gambling TM, Garcia R, Osnaya N et al. Ultrastructural nasal pathology in children chronically and sequentially exposed to air pollutants. Am J Resp Cell Mol Biol. 2001;24(2):132-8.

58. Cannell JJ. Epidemic influenza and vitamin D. Epidemiol Infect. 2006;134(6):1129-14

59. Sheffield PE, Landrigan PJ. Global climate change and children's health: threats and strategies for prevention. Environ Health Perspect. 2011;119(3):291-8 